\title{
10 Years of the Basic Law: the Rise, Retreat and Resurgence of Judicial Power in Hong Kong
}

\author{
Po-Jen Yap*
}

\begin{abstract}
Since the National People's Congress Standing Committee's (NPCSC) reversal of the Court of Final Appeal's abrasive decision of $\mathrm{Ng}$ Ka Ling, the court has become cognizant of the repercussions of its decisions and has now adopted a pragmatic view toward its adjudicatory role. Where decisions implicate the validity of Mainland Chinese laws or NPCSC decisions, the court would always defer to the central government. Notwithstanding the court's recognition of the supremacy of the NPCSC, the court has remained very diligent in preserving its prerogative as the primary interpreter of the Basic Law. Where disputes concern alleged human rights violations that have no People's Republic of China (PRC) implications but have law and order implications in Hong Kong, the courts are generally conservative so as to afford the legislature or the executive much latitude in maintaining peace and stability. With regard to disputes with neither NPCSC nor domestic law and order implications, the court is confident that any political backlash against an adverse decision would be minimal; in these instances, the court is therefore more conscious of avoiding the austerity of tabulated legalism and is enthused about providing a generous interpretation of the Basic Law.
\end{abstract}

\section{Introduction}

1 July 2007 marks the first decade of the People's Republic of China's (PRC) resumption of sovereignty over Hong Kong and the concomitant establishment of the Special Administrative Region (HKSAR) under the sacred but somewhat elusive principle of 'One Country, Two Systems'. After British rule, the Basic Law became the foundational constitutional instrument that governs the autonomous province. From

* LLB National University of Singapore, LLM Harvard, LLM London. Assistant Professor of Law, University of Hong Kong; e-mail: pjyap@hkucc.hku.hk. The author would like to thank Albert Chen and Johannes Chan for their helpful comments. All errors are the author's alone. 
the outset, the Hong Kong judiciary, tasked under the Basic Law to be the independent adjudicator between the government and the aggrieved citizenry, had the unenviable task of safeguarding the constitutionally enshrined fundamental liberties in the region whilst tending to the political sensitivities of the central government in China. This is no menial feat as it requires the preservation of the robust common law tradition within the confines of an essentially Chinese civil law instrument. The inevitable tussle for power between the judiciary, the executive branch of the Hong Kong government and the National People's Congress of the PRC was bound to ensue.

$\mathrm{Ng} \mathrm{Ka}$ Ling marked a milestone in the constitutional history of the HKSAR as the Court of Final Appeal (CFA), in its first decision after the handover, asserted the power to declare Hong Kong Ordinances unconstitutional. ${ }^{1}$ More controversially, the CFA also proclaimed that the Hong Kong judiciary had the requisite duty and power to declare any legislative acts of the National People's Congress (NPC) (or its Standing Committee, NPCSC) inconsistent with the Basic Law. ${ }^{2}$ This bold assertion naturally triggered the wrath of the Mainland and HKSAR government and was the catalyst to an unfortunate constitutional stand-off between the CFA and Beijing. Following a rabid chastisement that took the form of the First Interpretation by the Standing Committee of the NPC, the HK courts beat a hasty retreat in Lau Kong Yung wherein the CFA recognized the plenary powers of the NPC in constitutional interpretation. ${ }^{3}$ Their perceived abdication of the judicial duty to defend the rights of the Hong Kong people has naturally led to a general pessimism by academics about the fate of constitutional review in Hong Kong. ${ }^{4}$ Others, like Professor Albert Chen, have become more optimistic as he perceives the judiciary to have chosen the golden mean between confrontation with and subservience to Beijing'. ${ }^{5}$

In this paper, I would essentially argue that since $\mathrm{Ng} \mathrm{Ka} \mathrm{Ling,} \mathrm{the}$ CFA has become cognizant of the repercussions of its decisions and legislative/executive reaction as such and has now adopted a pragmatic view toward its adjudicatory role and is keenly conscious of the consequences of its actions. Where decisions implicate the validity of PRC laws or NPCSC decisions, the courts would always defer to the central government. Notwithstanding the CFA's recognition of the supremacy of the NPCSC, the court has remained very diligent in

1 [1999] 1 HKLRD 315 at 337.

2 Ibid.

3 [1999] 3 HKLRD 778 at 798.

4 T. Martin, 'Hong Kong Right of Abode: Ng Siu Tung \& Others v Director of Immigration-Constitutional and Human Rights at the Mercy of China' (2004) 5 San Diego International Law Journal 465 and S. Marsden, 'Regional Autonomy, Judicial Criticism and 2005 Interpretation: Judicial Independence in Hong Kong Compromised Again?', 36 Hong Kong Law Journal 117.

5 A. Chen, 'Constitutional Adjudication in Post-1997 Hong Kong' (2006) Pacific Rim Law and Policy Journal 627. 
preserving its prerogative as the primary interpreter of the Basic Law. Where disputes concern alleged human rights violations that have no PRC implications but have law and order implications in Hong Kong, the courts are generally conservative so as to afford the legislature or the executive much latitude in maintaining peace and stability. With regard to disputes with neither NPCSC nor domestic law and order implications, the CFA is confident that any political backlash against an adverse decision would be minimal; in these instances, the court is therefore more conscious of avoiding the austerity of tabulated legalism and is enthused about providing a generous interpretation of the Basic Law.

Section II of this paper begins with an expository tale of the $\mathrm{Ng} \mathrm{Ka}$ Ling saga. It will chart and critique the dramatic rise and retreat of judicial power over the course of one brief year. Sections III to V continue with a critical examination of the judicial record of the CFA after Lau Kong Yung. Section III will focus on those disputes that implicate relations with the central government; Section IV will explore cases with no Mainland dimensions but which implicate internal law and order concerns and finally Section V will examine conflicts with neither concern. Essentially, I will debunk the conventional wisdom that post First Interpretation, the appellate courts in Hong Kong are pursuing a consistent path of moderate liberalism; ${ }^{6}$ instead I will argue that the liberality of their decisions hinges on the consequences they pose to Mainland relations and internal law and order issues.

\section{Ng Ka Ling Saga}

In $\mathrm{Ng} \mathrm{Ka} \mathrm{Ling,} \mathrm{the} \mathrm{applicants} \mathrm{were} \mathrm{children} \mathrm{born} \mathrm{in} \mathrm{the} \mathrm{Mainland} \mathrm{to}$ Hong Kong permanent residents. Their appeal essentially hinged on whether their right of abode in Hong Kong, as provided under Article 24(3) of the Basic Law, ${ }^{7}$ had been contravened by two Immigration Ordinances passed by the Hong Kong Provisional Legislative Council days after the handover. Essentially, the Ordinances required Mainlanders who wished to exercise the right of abode arising by descent to satisfy Hong Kong's Director of Immigration that they were indeed permanent residents and subsequently to obtain the Mainland authorities' permission to leave for Hong Kong. Furthermore, the Ordinance imposed criminal sanctions retrospectively on parties who entered Hong Kong after the entry of the Basic Law but before the enactment of the relevant immigration provisions.

6 See ibid. at 630 .

7 Article 24 reads: 'The permanent residents of the Hong Kong Special Administrative Region shall be: (1) Chinese citizens born in Hong Kong before or after the establishment of the Hong Kong Special Administrative Region; (2) Chinese citizens who have ordinarily resided in Hong Kong for a continuous period of not less than seven years before or after the establishment of the Hong Kong Special Administrative Region; (3) Persons of Chinese nationality born outside Hong Kong of those residents listed in categories (1) and (2)'. 
On appeal to the CFA, the Chief Justice, on behalf of a unanimous bench, held that:

In exercising their judicial power conferred by the Basic Law, the courts of the Region have a duty to enforce and interpret that Law. They undoubtedly have the jurisdiction to examine whether legislation enacted by the legislature of the Region or acts of the executive authorities of the Region are consistent with the Basic Law and, if found to be inconsistent, to hold them to be invalid. ${ }^{8}$

This statement, though uncontroversial in light of Marbury v Madison ${ }^{9}$ and numerous justiciable Bills of Rights littered across the common law jurisdictions, is significant in so far as the CFA is asserting, in its first decision since the handover, that the judiciary would perform its constitutional role of acting as a constitutional brake on the legislative or executive excesses of the Hong Kong government.

More controversial is the CFA's next declaration that sparked off the inevitable stand-off with Beijing. Rather immodestly, the judiciary held that the Hong Kong courts have the jurisdiction and duty to declare any legislative acts of the NPC or its Standing Committee inconsistent with the Basic Law if so found ${ }^{10}$ Its reasons were threefold. First, the power of the Hong Kong courts to declare NPC acts inconsistent with the Basic Law was derived from the Sovereign (the NPC) given that the NPC had enacted, pursuant to Article 31 of the Chinese constitution, the Basic Law for the region. ${ }^{11}$ Second, as with other constitutions in the world, the Hong Kong courts had been vested with independent judicial power within the high degree of autonomy granted to the region and since it was for the Hong Kong courts to determine questions of legislative invalidity when they arose, this necessarily included the power to determine whether an act of the NPC is consistent with the Basic Law. ${ }^{12}$ Lastly, the court added that since the Basic Law was enacted to implement China's commitment, under the Joint Declaration with the British, to maintain the status quo in Hong Kong for 50 years as evidenced in Article 159(4) of the Basic Law, ${ }^{13}$ the duty of the Hong Kong courts to enforce and interpret the Basic Law necessarily entails the power to strike down acts of the NPC that flouted this principle. ${ }^{14}$

The first reason can be easily dismissed. Just because the NPC enacted the region's Basic Law pursuant to its powers under the Chinese constitution, it does not necessarily follow that the regional judiciary has been granted the power to declare the NPC's acts inconsistent with the regional constitution. The second rationale stands on

8 [1999] 1 HKLRD 315 at 337.

95 US 137 (1803).

10 [1999] 1 HKLRD 315 at 337.

11 Ibid.

12 Ibid. at 338.

13 Article 159(4) reads: 'No amendment to this Law shall contravene the established basic policies of the People's Republic of China regarding Hong Kong'.

14 [1999] 1 HKLRD 315 at 338. 
even weaker grounds. Even if Hong Kong has been granted a high degree of autonomy over internal issues and the courts independent judicial power such that they can invalidate local Ordinances for being inconsistent with the Basic Law, it does not follow that the NPC has granted the regional courts the prerogative to invalidate its decisions for being so.

The most compelling argument for the existence of this power lies in the third reason. If I may rephrase this argument, it goes as follows: if the Hong Kong courts do not have the power to invalidate NPC decisions for being inconsistent with the Basic Law, the regional courts would be impotent in the face of any attempt by China to breach its treaty obligations under the Joint Declaration or its constitutional obligation under Article 159(4) to preserve the established basic policies regarding Hong Kong. Seen in this light, arguably the Hong Kong courts' jurisdiction to enforce and interpret the Basic Law necessarily includes the jurisdiction to adjudicate over acts of the NPC to ensure consistency with the Basic Law. However, read against Article 158 of the Basic Law, the tenability of this reading collapses. Article 158(1) unambiguously (and unfortunately I may add) vests the power of interpretation in the Standing Committee of the NPC. Article 158(2) continues by adding that the Standing Committee is to 'authorize' the courts of Hong Kong to interpret, on their own, provisions of the Basic Law which are within the limits of the region's autonomy. Therefore, since pursuant to Article 158(2), the power of interpretation granted to the Hong Kong courts is a delegated power from the NPC, it is legally untenable for the grantee to possess the powers to override the acts of the grantor. Article 158(3) of the Basic Law confirms this reading:

If the courts of the Region, in adjudicating cases, need to interpret the provisions of this Law concerning affairs which are the responsibility of the Central People's Government, or concerning the relationship between the Central Authorities and the Region, the Courts of the Region shall, before making their final judgments which are non-appealable, seek an interpretation of the relevant provisions from the Standing Committee of the National People's Congress through the Court of Final Appeal of the Region. When the Standing Committee makes an interpretation of the provisions concerned, the courts of the Region, in applying those provisions, shall follow the interpretation of the Standing Committee. (emphasis supplied)

Certainly, the question of whether Hong Kong courts have the authority to invalidate NPC acts concerns the relationship between the Central Authorities and the Region' and in so far as the courts have a constitutional obligation to seek and abide by an Interpretation from the Standing Committee, the judiciary is therefore deprived of the power to invalidate NPC decisions for being inconsistent with the Basic Law. 
The second controversy surrounding $\mathrm{Ng}$ Ka Ling stemmed from the CFA's refusal to refer the interpretation of Articles 22(4) and 24(3) to the Standing Committee and the court's insistence on interpreting these provisions on its own. Essentially in $\mathrm{Ng} \mathrm{Ka} \mathrm{Ling,} \mathrm{the} \mathrm{CFA} \mathrm{was}$ confronted with two Basic Law provisions that ostensibly were in conflict. Article 22(4) states that for entry into Hong Kong, people from other parts of China must apply for approval from the competent authorities of the central government. Notwithstanding Article 22(4), Article 24(3) states that persons of Chinese nationality born outside Hong Kong to the region's permanent residents are to have the right of abode. The CFA held that such a duty to make a reference to the Standing Committee would only arise under Article 158 if two conditions were satisfied: (1) the Basic Law provisions under examination concern affairs which are the responsibility of the central people's government or the relationship between the central authorities and Hong Kong (henceforth termed 'the classification condition') and (2) the CFA needs to interpret such provisions as the interpretation will affect the judgment on the case (henceforth termed the necessity condition'). ${ }^{15}$ Interestingly, the court held that in deciding whether the classification condition is satisfied, the judiciary must first identify which is the predominant provision that has to be interpreted. If the predominant provision is an excluded provision, the court has an obligation to refer its construction to the Standing Committee; but if the predominant provision is not an excluded provision, 'no reference needs to be made, although an excluded provision is arguably relevant to the construction of the non-excluded provision even to the extent of qualifying it'. ${ }^{16}$

Unfortunately, the CFA did not reason but simply declared that Article 24 was the predominant provision and not Article 22, and since the former provision concerned the recognition of permanent residency in Hong Kong, it did not relate to the relationship between the central authorities and the region and a reference to the Standing Committee was unnecessary. The rationale the court gave for this conclusion was provided in one short half-hearted explanation which stated cursorily that Article 24 is the 'very source of the right which is sought to be enforced by the applicants in these appeals' ${ }^{17}$ Certainly the appellants were relying on Article 24 to establish their right of abode, but as to how that made Article 24 the predominant provision that trumped a conflicting Article 22, the CFA decided to leave us all in the dark.

Eminent Basic Law scholar Professor Albert Chen has since attacked the CFA's reasoning on two fronts. First, he argues that the 'necessity condition' should be addressed first before the 'classification condition' 
and not the inverse approach taken by the courts; after all there is nothing for the court to classify unless and until the court first identifies, by the use of the necessity condition, what particular provisions of the Basic Law need to be so classified. ${ }^{18}$ On this front, Albert Chen's critique is undoubtedly right and I will not labour the point further. His second criticism is more interesting. He argues that only Article 22(4) and not Article 24 is necessary for the purpose of deciding the issues in $\mathrm{Ng} \mathrm{Ka} \mathrm{Ling} \mathrm{because,} \mathrm{so} \mathrm{far} \mathrm{as} \mathrm{the} \mathrm{exit} \mathrm{permit} \mathrm{scheme} \mathrm{regulat-}$ ing Mainlanders' entry into Hong Kong is concerned, the interpretation of Article 24(2) and (3) is irrelevant and the court has erred in not referring the interpretation of Article 22(4) to the Standing Committee. ${ }^{19}$ As explained by Albert Chen, "There is nothing ambiguous in the wording of Article 24(3). The ambiguity lies in the wording of Article 22(4)'. ${ }^{20}$ Unfortunately, I would beg to differ. The ambiguity surrounding Article 24(2) and (3) concerns whether the right of abode conferred on Mainland-born Chinese citizens taking residency status by descent is either independent of or qualified by the Article 22 regulatory scheme which the CFA conceded rightly to be an excluded provision. Where we have two conflicting Basic Law provisions, one which falls within the limits of the autonomy of the region and another which concerns the relationship between the responsibility of the central authorities and the region, it is impossible to adjudicate on one provision independent of the other, and I would thus have argued that it would have been necessary to refer this conflict between Article 22 and Article 24, that is to say, to refer both provisions, to the Standing Committee, as a conflict between both provisions cannot be reconciled in isolation from one another. Therefore the gist of this interpretive controversy stems not from the ambiguity of Article 22 per se, but the apparent conflict between Article 24 and Article 22. Similarly, the CFA's touchstone 'predominant provision' test is flawed: where there are two conflicting Basic Law provisions, one which falls within the prerogative of the central government, ipso facto this conflict should be resolved by the Standing Committee. In any case, as argued further, the CFA has been disingenuous about the application of such a test, as it paid scant attention as to how the predominant provision may be identified and merely arbitrarily declared Article 24 to be predominant.

Consequently, the CFA held that the Immigration Ordinance was unconstitutional to the extent that it required permanent residents of the region residing on the Mainland to hold a one-way permit before they could enjoy the constitutional right of abode. ${ }^{21}$ To the extent that the Ordinance applied retrospective criminal sanctions, the court

18 A. Chen, 'Ng Ka Ling and Article 158(3) of the Basic Law' (2001-2002) Journal of Chinese and Comparative Law 222 at 227.

19 Ibid. at 234.

20 Ibid.

21 [1999] 1 HKLRD 315 at 348. 
readily excised the impugned provisions. ${ }^{22}$ Furthermore, the court also invalidated a statutory bar that excluded the recognition of permanent residency for illegitimate Mainland children born to men who were Hong Kong permanent residents. ${ }^{23}$ In the same vein, the CFA in Chan Kam Nga, a judgment issued on the same day as $\mathrm{Ng} \mathrm{Ka} \mathrm{Ling,}$ invalidated a statutory bar that limited the right of abode to children who were born after and not before their parents acquired permanent residency in Hong Kong. ${ }^{24}$

The CFA's bold and unequivocal assertion of judicial power was welcomed by human rights commentators who were worried that the promise of autonomy under the Basic Law would prove to be illusory after the handover. Naturally, the central government and those within its inner sanctum were not amused and perceived the CFA's gratuitous grab for power as a direct challenge to its sovereignty and interpretive mandate. ${ }^{25}$ The Hong Kong government, on the other hand, was more concerned about the practical ramifications that would result from the massive influx of immigrants from the Mainland and the strain this would impose on the province's healthcare, housing and social welfare system. An application for the CFA to 'clarify' its decision in $\mathrm{Ng} \mathrm{Ka}$ Ling was thus sought and in light of the controversy which the decision had engendered, the court acceded to the request and issued its clarification. In a very terse judgment, the court accepted that the Standing Committee had the authority to issue a constitutional Interpretation under Article 158 which would have to be followed by the courts of the region. ${ }^{26}$ But more interestingly, the court followed this concession with a veiled re-assertion of judicial power:

The Court accepts that it cannot question, the authority of the National People's Congress or the Standing Committee to do any act which is in accordance with the provisions of the Basic Law and the procedure therein. ${ }^{27}$

What the CFA left deliberately unspoken was the court's amenability to the questioning and subsequent invalidation of the acts of the NPC or the Standing Committee which it deems not to be in accordance with the Basic Law. Strangely, the subversive nuances in $\mathrm{Ng} \mathrm{Ka} \mathrm{Ling}$ (No 2) were lost on the central government and Beijing was sufficiently appeased by the clarification. ${ }^{28}$ The Hong Kong government

22 Ibid. at 352.

$23 \mathrm{Ibid}$. at 354.

24 [1999] 1 HKLRD 304.

25 M. O'Neill, 'Beijing Says Abode Ruling was Wrong and Should Be Changed' (1999, 9 Feb) South China Morning Post (Hong Kong).

26 [1999] 1 HKLRD 577 at 578.

27 Ibid.

28 The NPC chose neither to address the $\mathrm{Ng} \mathrm{Ka} \mathrm{Ling} \mathrm{ruling} \mathrm{at} \mathrm{its} \mathrm{annual} \mathrm{plenum}$ session nor refer the matter to the Standing Committee. See 'One Country, Two Legal Systems?' Report of the Joseph Crowley Program (1999) 23 Fordham International Law Journal 1. 
was, however, not to be deterred or dissuaded. First, the government waged a media war by raising the ominous spectre of 1.67 million Mainlanders trooping into Hong Kong over the next seven years with catastrophic consequences on governmental resources, ${ }^{29}$ thereby turning the tide of public opinion against the court. Next, the SAR government returned to Beijing and sought an Interpretation from the Standing Committee to reverse $\mathrm{Ng} \mathrm{Ka} \mathrm{Ling} \mathrm{definitively.}$

The Standing Committee issued its First Interpretation under the Basic Law on 26 June 1999, stating unequivocally that Mainland children born to Hong Kong permanent residents must obtain the requisite exit permits before they can acquire the right of abode in Hong Kong and for this right to arise under Article 24(3), either parent must be a Hong Kong permanent resident at the time of the child's birth. ${ }^{30}$ Whilst the Interpretation did not disturb the CFA's extension of the right of abode to illegitimate children of Hong Kong permanent residents, and excluded the parties in the $\mathrm{Ng} \mathrm{Ka} \mathrm{Ling/Chan} \mathrm{Kam} \mathrm{Nga}$ litigation from its application, the rights of all others would be determined by reference to this Interpretation. ${ }^{31}$

Following this rabid chastisement, the CFA eventually caved in in Lau Kong Yung when the court recognized the complete and plenary powers to interpret every provision of the Basic Law:

The power of interpretation of the Basic Law conferred by Article 158(1) is in general and unqualified terms. ${ }^{32}$

This was a major concession by the court as it recognized the freestanding general interpretive mandate that the Standing Committee possessed, an unqualified power it had not previously affirmed in $\mathrm{Ng}$ Ka Ling (1) or (2). There were many options open to the court. It could have held, as counsel for the abode seekers argued, that the Standing Committee could only issue an Interpretation upon a judicial reference by the court over a dispute relating to the excluded provisions. This option was rightly rejected. As recognized by the court, the authority delegated by Article 158(2) and (3) to the courts stems from the general power of interpretation vested in the Standing Committee under Article 158(1). To accept counsel's submission would be to deny the Standing Committee the power to interpret all provisions of the

29 Chris Yeung, 'The Cost of Dealing with This Dilemma' (1999, 8 May) South China Morning Post (Hong Kong) 15. See Fung Ho-lup, 'The Right of Abode Issue' in Wong Yiu-Chung (ed.), One Country, Two Systems in Crisis: Hong Kong's Transformation since the Handover (Lexington Books: Lanham, MD, 2004) where the author discussed how the statistics provided by the government were grossly inflated.

30 See Interpretation by the Standing Committee of the NPC on Arts. 22(4) and 24(2)(3) of the Basic Law of the Hong Kong SAR, http://www.info.gov.hk/ basic_law/fulltext.

31 See ibid., para. 2.

32 [1999] 3 HKLRD 778 at 798. 
Basic Law save the excluded provisions; a position inconsistent with the general power conferred by Article 158(1). ${ }^{33}$

Notwithstanding the CFA's recognition of the supremacy of the NPCSC's Interpretation, the court interestingly announced that the No 3 Ordinance, s. 1(2) was still unconstitutional. ${ }^{34}$ Although the Interpretation resurrected the legality of the Ordinance in so far as it sought to subject Mainland children born to Hong Kong permanent residents to the regulatory exit permit scheme, the court held that the Interpretation was silent on the Ordinance's second basis for infirmity, namely that it attempted to impose criminal sanctions retrospectively on parties who entered Hong Kong after the enactment of the Basic Law but prior to the enactment of the statute on 9 July $1997 .{ }^{35}$ Since this ground was not affected by the Interpretation, the court held that the retrospective provision remained invalid. Admittedly, this judicial manoeuvre had minimal practical impact, that is it only protected immigrants who arrived in Hong Kong between 1 and 10 July from criminal sanctions; but the significance of this holding lay in the judicial methodology applied. From henceforth, whilst the courts would respect and abide by the free-standing interpretive mandate of the NPCSC, the Interpretation would be read narrowly and strictly. The message was clear: the court would remain the primary albeit not final interpreter of the Basic Law.

Moreover, nowhere in Lau Kong Yung did the court retract its earlier pronouncement in $\mathrm{Ng} \mathrm{Ka} \mathrm{Ling} \mathrm{that} \mathrm{it} \mathrm{had} \mathrm{the} \mathrm{power} \mathrm{to} \mathrm{declare}$ acts of the NPC or NPCSC inconsistent with the Basic Law. Reading Lau Kong Yung against $\mathrm{Ng} \mathrm{Ka} \mathrm{Ling,} \mathrm{it} \mathrm{would} \mathrm{appear} \mathrm{that} \mathrm{the} \mathrm{court}$ only conceded that an NPC Interpretation was final; absent an Interpretation, the judiciary would remain amenable to the invalidation of NPC acts which they deem inconsistent with the Basic Law.

\section{The CFA and the Central Government}

Shortly after deciding Lau Kong Yung, the CFA handed down another politically charged judgment in $\mathrm{Ng} \mathrm{Kung} \mathrm{Siu.}{ }^{36}$ In that case, the accused argued that the statutory sanctions against the desecration of the national and regional flags were unconstitutional violations of their freedom of expression as protected under Article 27 of the Basic Law. The CFA disagreed, stating instead that there were legitimate societal interests in keeping the symbols of nationhood and sovereignty above the strife of politics. ${ }^{37}$ Furthermore, the criminal prohibition against flag desecration was a limited restriction of the freedom of expression as it banned only one mode of expression and did not interfere with a 
person's freedom to express the same message by other means. ${ }^{38}$ Naturally the CFA's reasoning did not sit well with many scholars. Raymond Wacks in particular waxed lyrical about Hong Kong's flagging rights and lamented that the court's conclusion undermined its own asseveration that the freedom of expression lies at the heart of Hong Kong's way of life and the courts' exhortation about giving a generous interpretation to this constitutional guarantee which includes the right to express ideas which the majority and the government may find offensive. ${ }^{39}$

My intention here is not to discuss the inadequacies of the CFA's legal reasoning, for Wacks has done so more than adequately and with much flourish. Instead my purpose is to explore what the CFA did not discuss. Ostensibly the CFA was dealing with the constitutionality of two Ordinances, but what the court was actually avoiding was the invalidation of a PRC law. Pursuant to Article 18(2) and (3) of the Basic Law, ${ }^{40}$ the NPCSC had the power to apply to Hong Kong Mainland laws that relate to affairs falling outside the limits of the region's autonomy. The National Flags Ordinance was the local implementation of the PRC Law on the National Flag applied to Hong Kong via Article 18(3). The CFA was thus reluctant to declare the NPCSC's act of applying this PRC law to Hong Kong as being inconsistent with the Basic Law, a power it had asserted in $\mathrm{Ng} \mathrm{Ka} \mathrm{Ling} \mathrm{but} \mathrm{had} \mathrm{relinquished}$ in Lau Kong Yung, as this would only trigger another Interpretation. Nor did the judiciary want to set a precedent and make a reference to the NPCSC on this matter, which ostensibly it should since the application of this law, as classified by the NPCSC, related to affairs outside the limits of Hong Kong's autonomy, especially since this concerned a cherished right as fundamental as the freedom of expression. In light of all these possibilities, about which the court must have been aware but remained silent in its judgment, the CFA probably decided that the most politically viable path was to uphold the impugned legislation. Given that flag desecration is symbolic speech and its message could be communicated in many alternative ways, the CFA, in the interests of safeguarding its long-term autonomy and independence, probably chose the wiser option of allowing our flag-burning rights to go up in smoke.

In sharp contrast to $\mathrm{Ng}$ Kung Siu was the judicial approach taken in the right of abode case of Chong Fung Yuen. ${ }^{41}$ Here the Chinese applicant was born in Hong Kong to parents who were not Hong

38 Ibid.

39 R. Wacks, 'Our Flagging Rights' (2000) HKLJ 1 at 3.

40 The Basic Law, Art. 18(3) reads: 'The Standing Committee of the National People's Congress may add to or delete from the list of laws in Annex III after consulting its Committee for the Basic Law of the Hong Kong Special Administrative Region and the government of the Region. Laws listed in Annex III to this Law shall be confined to those relating to defence and foreign affairs as well as other matters outside the limits of the autonomy of the Region as specified by this Law'.

41 [2001] 2 HKLRD 533. 
Kong permanent residents and he asserted his right of abode under Article 24(1) which expressly provides that Chinese citizens born in Hong Kong before or after the establishment of the HKSAR are Hong Kong permanent residents. This plain, literal reading unfortunately conflicts with an Immigration Ordinance which limits the enjoyment of the right of abode to children born to Hong Kong permanent residents.

The CFA rightly rejected the Director of Immigration's contention that in deciding whether Article 24(1) was an excluded provision that required referral to the NPC, the legal test would be whether its implementation would have a 'substantive effect' on the Mainland. ${ }^{42}$ Otherwise, most if not all the Articles in the Basic Law could potentially be excluded provisions and this would spell the end of Hong Kong's judicial autonomy. In its place, the CFA asked whether the disputed provision had the 'character' of one which concerns affairs which are the responsibility of the central government or the relationship between the central authorities and the region, but the CFA did not offer any general guidance for determining the character of the Basic Law provisions. ${ }^{43}$ All it did was to provide this pithy explanation that the 'character' of Article 24(1) was one that falls within the region's autonomy:

Its character is that of a provision defining one category of permanent residents who are entitled to the right of abode. ${ }^{44}$

This conclusion is very puzzling. Article 24(3), the disputed provision in $\mathrm{Ng} \mathrm{Ka} \mathrm{Ling,} \mathrm{also} \mathrm{defined} \mathrm{one} \mathrm{category} \mathrm{of} \mathrm{permanent} \mathrm{residents} \mathrm{who}$ are entitled to the right of abode, but its conflict with Article 22(4), an excluded provision, required resolution by the NPCSC. In my view, the CFA should have instead asked whether the disputed provision concerns a matter that falls within or conflicts with a power expressly retained by the central government under the Basic Law, for example Articles 13, 14, 15 and 22(4). Where the adjudication of a disputed provision does not fall within or conflict with the power expressly retained by the central government or NPC under the Basic Law, the matter falls within the limits of autonomy delegated to the regional courts and a judicial reference to the NPCSC is unnecessary.

Even if the CFA was not required to refer the interpretation of Article 24(1) to the NPCSC, it was still faced with two powerful arguments that would exclude Chinese citizens born in Hong Kong to nonpermanent residents from enjoying the right of abode.

First, as argued by the Director of Immigration, reading Article 24(1) in light of its purpose and context did not confer on such persons the right of abode. The CFA admitted in Chong that this was the interpretive methodology it would apply: 
When interpreting the provisions that define the categories of permanent residents, the courts should simply consider the language in light of any ascertainable purpose and context. ${ }^{45}$

Naturally, to ascertain the purpose and context of these provisions, the judiciary would have to turn to extrinsic materials such as pre- or post-enactment legislative aids for guidance. ${ }^{46}$ However, the CFA rather astutely did not want to open the floodgates and allow for the introduction of Mainland legal materials into Hong Kong's constitutional discourse and flatly reversed this mode of interpretation a few paragraphs later:

The courts are bound to give effect to the clear meaning of the language. The courts will not on the basis of any extrinsic materials depart from that clear meaning and give the language a meaning which the language cannot bear. ${ }^{47}$

By applying a plain, literal reading of the text, the court granted the right of abode to the applicant and eschewed the prospect of admitting Mainland legislative internal aids into Hong Kong's constitutional litigation. The court was totally disingenuous but absolutely ingenious.

Not content to leave matters at that, the court proceeded and gently reminded its Mainland audience that:

Under a common law system which includes a separation of powers, the interpretation of laws once enacted is a matter for the courts. ${ }^{48}$

But to pre-empt any outcry from the Mainland, the court was quick to add that the court's power would always be bound by any Interpretation by the Standing Committee under Article 158.

Second, the fact remained that in the earlier NPCSC Interpretation, the text included a passage which provided that the legislative intent of all other categories of Article 24(2) of the Basic Law' had been reflected in the Opinion of Preparatory Committee for the establishment of the HKSAR. More significantly, under Chinese law, legislative interpretations have the force of statutory enactments. ${ }^{49}$ Notwithstanding this, the CFA skirted the issue by stating the following:

On the common law approach, which the court is under a duty to apply in the absence of a binding interpretation by the Standing Committee, the statement in question cannot affect the clear meaning of Art. 24(1) properly reached, applying the common law approach. ${ }^{50}$

45 Ibid. at 546.

46 Moreover, it is disputable whether extrinsic materials such as the Preparatory Opinions for the establishment of the HKSAR were mere statutory aids since under the canons of Chinese civil law interpretation, once the Preparatory Opinions are adopted by the national legislature, they would have the same legal effect as a national law validly enacted by the NPC. See Lin Feng, Chinese Constitutional Law (Sweet \& Maxwell Asia, 2000) 107-11.

47 [2001] 2 HKLRD 533 at 547.

48 Ibid.

49 A. Chen, 'The Interpretation of the Basic Law' (2000) 30 HKLJ 380 at 411-16.

50 [2001] 2 HKLRD 533 at 555. 
The court seemed to suggest that the objective of an Interpretation was directed at resolving the tensions between Articles 22(4) and 24(3) and thus the unfortunate passage in the Interpretation was merely obiter dicta and thus not binding on the Hong Kong courts. The main difficulty with this reasoning is not that the court purported to uphold the common law approach of distinguishing ratio decidendi from obiter dicta. The controversy in my view concerns the legal grounds which the court had for classifying the Interpretation not as a statutory enactment, with all provisions binding on the court, but seemingly as a superior court judgment with only its ratio binding. After all, even under the common law tradition, if the Interpretation was legislation, the courts would not have the power to decide which statutory provisions are obiter and need not be enforced. Naturally, the CFA did not offer a shred of legal reasoning as to why the Interpretation should be viewed like a judgment and not legislation.

The Chong decision should thus be celebrated, not for upholding the common law tradition (because the CFA was making up its own legal tradition as it went along); it should instead be lauded for the judicial astuteness shown by the CFA in asserting its autonomy in a political environment which it knew it could win. The Director of Immigration had conceded that an adverse decision against him would not give rise to an immediate influx of Mainlanders, unlike the tidal wave of immigration that $\mathrm{Ng} \mathrm{Ka}$ Ling potentially generated. ${ }^{51}$ Only 555 children per annum would be eligible for the right of abode this time. The court was thus confident that the government would not be able to orchestrate another media blitz forecasting the doom and gloom of Hong Kong and reverse the court's decision with another request to Beijing. The court must have known that this was an opportune time as good as any to assert its own autonomy and defend the rights of abode seekers coming by its protective shores.

This judicial awareness of political fallout was once again displayed in $\mathrm{Ng}$ Siu Tung. ${ }^{52}$ In this case, the Mainland-born applicants to Hong Kong permanent residents argued that they could claim the right of abode, notwithstanding the NPC Interpretation, as they had received either (1) general oral representations from senior government officials both before and after the judgments of $\mathrm{Ng} \mathrm{Ka}$ Ling and Chan Kam Nga that the government would abide by the court's ruling, or (2) specific written representations to individual applicants by the Director of Immigration to the same effect, such that in either case, they had a substantive legitimate expectation to be treated in the same way as the actual claimants in those two litigations.

The majority in $\mathrm{Ng}$ Siu Tung eventually ruled in favour of those applicants who had received specific written representations from the government that they would be treated in the same way as the actual 
claimants in $\mathrm{Ng}$ Ka Ling and Chan Kam Nga, because they formed only 'a discrete, ascertainable class' ${ }^{53}$ of about 1,000 claimants, as opposed to those who had received general oral representations and whose number exceeded 600,000. ${ }^{54}$ For the former group of applicants, the removal orders against them were quashed and the Director of Immigration had to decide afresh their applications to stay in Hong Kong. This distinction drawn between the written representations and oral promises is legally dubious or highly technical at best. As the dissenting judge, Justice Bokhary, pointed out:

\begin{abstract}
All these representations, even those in the form of a communication to an individual, are in substance of the kind directed to a class. The class is the one made up of persons who would benefit from the application to them of the judgments in favour of the abode seekers in $\mathrm{Ng} \mathrm{Ka} \mathrm{Ling's}$ case and Chan Kam Nga's case. ${ }^{55}$
\end{abstract}

Nevertheless this result was probably inevitable and for the best. The CFA was probably cognizant that to accept that the general representees had a substantive legitimate expectation to seek a right of abode in Hong Kong would in effect be defying the central tenor of the NPC Interpretation, a prospect which the court could no longer stomach.

\title{
IV. The CFA and Domestic Law and Order
}

In the realm of crime control, the CFA's record has been starkly conservative. In upholding the mandatory nature of the life sentence for all persons convicted of murder, the court disagreed that the imposition of such a uniform punishment was arbitrary even though the moral probity of a mercy killer differs from that of a sadist. ${ }^{56}$

Even where the court 'read down' a statutory presumption, requiring an accused charged with the possession of an imitation firearm to prove he had a lawful excuse, to an evidential burden of production, the CFA did so knowing that the prosecution should have no abnormal difficulty in proving the purpose of the defendant's possession where that possession is for an unlawful purpose' ${ }^{57}$ Furthermore, the court declined to read down the impugned statutory presumption to cover just possession of an imitation firearm in a public place, preferring to preserve instead the application of the provisions over the entire geographical area which the legislature intended, namely private or public premises. ${ }^{58}$ This decision would not be so contentious but for the fact that the court, earlier in the judgment, had distinguished two English decisions which upheld a reverse onus in

53 Ibid. at 613.

54 Ibid.

55 Ibid. at 674.

56 Lau Cheong v HKSAR [2002] 2 HKLRD 612 at 644.

57 HKSAR v Lam Kwong Wai [2006] 3 HKLRD 808 at 830.

58 Ibid. at 838. 
relation to the offence of being in possession of a bladed knife, merely on the ground that the English offence was confined to possession in a public place. ${ }^{59}$ After all, I would have thought that if the geographical scope of the law was the basis for distinguishing the English offence, the natural way of reading down the impugned Hong Kong law would be for the CFA to read down its geographical applicability, but the judges admittedly were reluctant to 'drastically reduce the area of operation' 60 of the Ordinance.

Most recently, in So Wai Lun, the CFA upheld the constitutionality of a penal code which criminalized the conduct of the male to the exclusion of the female when he engages in unlawful sexual intercourse with a girl under the age of $16 .{ }^{61}$ In dismissing the argument that the statute was not discriminating against men, what is disconcerting is not so much the court's conclusions but its legal reasoning or more accurately lack thereof. The court was dutiful in listing the various legislative rationales for the law, namely:

the problem of teenage pregnancies; not criminalizing the female's conduct because that might deter her from reporting the matter, the legislature's role in resolving issues engaging society's code of sexual morality; and the extent to which it was for the legislature to form a view on issues as to whether the initiative in these matters is generally taken by the male, ${ }^{62}$

but summarily decided, without any legal analysis, that the means taken by the legislature was proportionate to the ends. ${ }^{63}$ All its prior exhortation about giving a generous interpretation to the Chapter III (Fundamental Rights) provisions of the Basic Law was conveniently forgotten. ${ }^{64}$

An interesting deviation from the CFA's usual conservative stance on law and order issues arose in Yeung May Wan. ${ }^{65}$ Sixteen peaceful demonstrators were convicted in the magistrates' court for obstruction of a public place and assault. The CFA quashed their convictions on the basis that the obstruction posed by the demonstrators was reasonable and, since the original arrest by the police was illegal, the demonstrators' resistance to an unlawful arrest was thus justified. ${ }^{66}$ This decision would hardly be of any constitutional significance but for the identities of the accused and the complainants. The demonstrators belonged to a religious sect known as the Falun Gong which

59 See $R$ v Matthews [2003] 2 Cr App R 19 and L v DPP [2003] QB 137; and see [2006] 3 HKLRD 808 at 828.

60 [2006] 3 HKLRD 808 at 838.

61 [2006] 3 HKLRD 394.

62 Ibid. at 403.

63 Ibid.

64 See $\mathrm{Ng}$ Ka Ling, above n. 1 at 340.

65 [2005] 2 HKLRD 212.

66 Ibid. at 247. 
has been severely prosecuted in mainland China since $1999 .{ }^{67}$ To complicate matters, this demonstration had taken place outside the Liaison Office of the Central People's Government in Hong Kong and the police report was lodged by staff members of the Liaison Office. It is against this political backdrop that we can better appreciate the CFA's exhortations of liberty for all, including the freedoms of the persecuted and the oppressed:

The freedom to demonstrate is a constitutional right. It is closely associated with the freedom of speech. These freedoms of course involve the freedom to express views which may be found to be disagreeable or even offensive to others or which may be critical of persons in authority. ${ }^{68}$ (emphasis supplied)

Two months later, the CFA handed down another landmark judgment relating to the freedom of assembly. ${ }^{69}$ This time the court was considerably more subdued. The defendants had organized a public procession of between 40 and 100 people without prenotifying the police as required under the law. After their arrests, they challenged the constitutionality of the legislation on the basis that the statutory discretions conferred on the police commissioner to object to a notified public procession and to impose conditions if he reasonably considered them to be necessary, in the interests of national security or public safety or public order (ordre public) or the protection of rights and freedom of others, are too wide and uncertain. ${ }^{70}$ The majority on the bench upheld the notification requirement but accepted that the commissioner's power to restrict peaceful assembly for the public order (ordre public) was constitutionally vague and thus severed 'ordre public' from public order in the 'law and order' sense. ${ }^{71}$ Since the defendants had not complied with the notification procedures, the severance of the constitutionally invalid provisions did not affect their appeal and their convictions were confirmed.

The reasoning of the CFA was unfortunately seriously flawed. The court accepted that for a rights-infringing law to pass constitutional muster, it must be necessary and proportionate. ${ }^{72}$ Yet nowhere in the judgment did the CFA explain why it was necessary and proportionate for the commissioner to possess the powers of prior restraint. Nowhere in the judgment did the court explain why 'public order' in the law and order sense was constitutionally certain and clear. It merely asserted so. ${ }^{73}$ In fact all the various statutory grounds for

67 See A. Cheung, 'In Search of a Theory of Cult and Freedom of Religion in China: The Case of Falun Gong' (2004) Pacific Rim Law and Policy Journal 1.

68 [2005] 2 HKLRD 212 at 216.

69 Leung Kwok Hung v HKSAR [2005] 3 HKLRD 164.

70 Ibid. at 176.

71 Ibid. at 196.

72 Ibid. at 183.

73 Ibid. at 196. 
prohibiting notified processions were wide and vague. As pointed out by the lone dissenting judge, Justice Bokhary:

National security, public safety and public order are very wide concepts. The protection of the rights and freedoms of others is a particularly wide concept. For there are so many rights and freedoms that others have, and the challenged schemes do not say which of these may be protected by police powers regarding public assembly. This is a serious omission. ${ }^{74}$

The CFA merely obliterated one vague concept from the impugned regulatory scheme and upheld the rest without explaining why. This is a serious omission. In fact despite the court's opening roar about the 'cardinal importance' of the 'precious' right to freedom of assembly and how it lies at the foundation of a democratic society, the rhetoric rang hollow in light of the actual result reached by the court. The practical benefits of this decision to potential demonstrators are minimal, especially since the commissioner retains a host of at large, broad powers to prohibit or restrain the organization of public processions in Hong Kong. ${ }^{75}$

At first blush, it might be difficult to reconcile Yeung with Leung as it is difficult to conceive why the CFA would have such a dramatic change of mind over the short span of two months. Perhaps in Yeung the CFA was cognizant that if the court had caved in to the pressures from the Mainland government, where the validity of a NPCSC Interpretation or NPC law was not at stake and where the court was adjudicating over a matter within the limits of Hong Kong's autonomy, not only would the independence of this sacred institution be questioned, the viability of the 'One Country, Two Systems' principle would be impugned. As Chief Justice Li reminded his readers in Yeung:

These freedoms are at the heart of Hong Kong's system and it is well established that the courts should give a generous interpretation to the constitutional guarantees of these freedoms in order to give to Hong Kong residents their full measure. ${ }^{76}$ (emphasis supplied)

The ultimate acquittal of the Falun Gong members was not just about the vindication of the rule of law in Hong Kong. Their victory attests to the CFA's commitment to safeguarding the 'One Country, Two Systems' principle and to treat all members of Hong Kong society equally, even and especially those derided and persecuted by the central government. On the other hand in Leung, where the CFA was adjudicating over a law and order tussle between the state and the individual with no central government implications, the court merely reverted to its general conservative stance on crime control issues. It

74 Ibid. at 229.

75 See J. Baryon, 'Leung Kwok Hung and Others through the Hong Kong Courts' (2006) 36 HKLJ 83.

76 [2005] 2 HKLRD 212 at 218. 
seems that the decision in Yeung was just an anomaly and not the norm.

Notwithstanding the conservative stance of the CFA toward law and order issues, the court has been very conscious about preserving/ consolidating its powers whilst arriving at decisions that are palatable to the executive.

In A Solicitor v Law Society, ${ }^{77}$ the CFA declared a finality clause, which statutorily abrogated the right of the CFA to hear appeals under the Legal Practitioners Ordinance, inconsistent with the Colonial Laws Validity Act $1865^{78}$ and hence, according to the court, the impugned provision did not form part of the laws of the Hong Kong SAR upon its establishment. ${ }^{79}$

As reasoned by the CFA, since the Orders in Council of 1909 (as amended in 1957) and 1982 provided that appeals from Hong Kong would lie (1) as of right from any judgment of the Court of Appeal where the matter in dispute amounted to more than a specified monetary amount, or (2) by special leave of the Privy Council, the finality clause that abrogated all appeals to the CFA (the successor body of the Privy Council) would be repugnant to the Colonial Laws Validity Act (CLVA) 1865. Certainly the finality clause is inconsistent with the CLVA 1865, but I question the CFA's right to make such a declaration. Whilst Article 160 of the Basic Law grants the CFA the power to declare Ordinances inconsistent with the Basic Law, there is no Basic Law or other statutory provision that permits the court to invalidate Ordinances for being inconsistent with the CLVA 1865. The court never explained why it had the power to make such a declaration and merely asserted that the repugnant finality provision was absolutely void and inoperative from the outset. ${ }^{80}$ Certainly the finality clause may have been repugnant as against the CLVA 1865 before the handover but given that it was never invalidated by the Privy Council, its validity as law previously in force in Hong Kong is preserved under Article $8^{81}$ of the Basic Law after the handover. The CFA left unanswered why it had the power to declare a law, whose validity was preserved by the Basic Law, inconsistent with a defunct foreign statute, no longer in force in Hong Kong after the handover.

77 [2004] 1 HKLRD 214.

78 The Colonial Laws Validity Act 1865, s. 2 provided: 'Any Colonial Law which is or shall be in any respect repugnant to the Provisions of any Act of Parliament extending to the Colony to which such Law may relate, or repugnant to any Order or Regulation made under authority of such Act of Parliament, shall be read subject to such Act, Order or Regulation, and shall, to the Extent of such Repugnancy, but not otherwise, be and remain absolutely void and inoperative'.

79 [2004] 1 HKLRD 214 at 224.

80 Ibid. at 223.

81 The Basic Law, Art. 8 reads: 'The laws previously in force in Hong Kong, that is, the common law, rules of equity, ordinances, subordinate legislation and customary law shall be maintained, except for any that contravene this Law, and subject to any amendment by the legislature of the Hong Kong Special Administrative Region'. 
Fortunately, in the alternative, the court had examined the consistency of the finality clause with the Basic Law and held that the impugned provision would in any event also be incompatible with the constitutional mandate of Article 82 which vests the power of final adjudication in the CFA. ${ }^{82}$ Interestingly, the CFA conceded that, although it had the power of final adjudication under Article 82, this was not an absolute mandate as limitations on appeal may be placed by the legislature so long as they pursue a legitimate purpose and there must be reasonable proportionality between the limitation and the purpose sought to be achieved. ${ }^{83}$ Hence, this particular finality clause fails for abrogating the right of appeal to the CFA totally. What is curious about this portion of the judgment is not what the CFA said but what the court omitted. In his written submissions, the Secretary of Justice had justified the finality clause on the basis that Article 83 provides for the structure, powers and functions of the courts of the HKSAR at all levels to be prescribed by law. ${ }^{84}$ Taken to its logical conclusion, the legislature can thus technically preclude the CFA from hearing any appeals. Fully aware of the implications of Article 83, it would appear that the court, in its usual fashion of ignoring difficult provisions, astutely settled on a compromise that preserves its position as the final adjudicator of its own jurisdiction whilst providing an avenue for the legislature to regulate the court's jurisdiction statutorily in the interests of justice and efficiency.

The same political astuteness was exercised by the court in Prem Singh. ${ }^{85}$ There, the CFA had to decide on the constitutionality of a statutory immigration scheme that required the Director of Immigration to grant a foreign national unconditional stay in Hong Kong before the latter could obtain permanent resident status under Article 24(4) which grants a non-Chinese citizen the right of abode when he has been an ordinary resident in Hong Kong for seven continuous years.

The CFA unanimously held that this statutory provision was unconstitutional, though it is interesting to compare the rationale put forward by Justice Ribeiro on behalf of the majority and that proffered by Justice Bokhary in his separate concurrence. The majority reasoned that since the non-Chinese applicant would have been subject to a limit of stay while building up his seven-year continuous period of ordinary residence, Article 24(4) therefore implicitly regards satisfaction of the permanent requirement as achievable at a time when an applicant is still subject to a limit of stay. ${ }^{86}$ Therefore the

82 [2004] 1 HKLRD 214 at 228.

83 Ibid. at 226.

84 See P. Y. Lo, 'Master of One's Own Court' (2004) HKLJ 47 at 60. The Basic Law, Art. 83 reads: 'The structure, powers and functions of the courts of the Hong Kong Special Administrative Region at all levels shall be prescribed by law'.

85 [2003] 1 HKLRD 550.

86 Ibid. at 572. 
legislative requirement that the applicant is not to be subject to any limit of stay after the seven years has accrued would be imposing an additional requirement incompatible with the requirements of the Basic Law. The majority's cautious, logical, but nonetheless legalistic reasoning contrasted sharply with Justice Bokhary's flourish in sweeping aside the impugned provision:

Indeed the notion of any legal right, let alone a constitutional right, being downgraded to something which can be granted or withheld as a matter of discretion is repugnant to the rule of law. ${ }^{87}$

Given that the Director of Immigration had no right to grant conditional stays after the applicant had ordinarily lived in Hong Kong for seven years, the court thereby backdated the relevant qualifying period for permanent residency to the date when the applicant first applied for unconditional stay. ${ }^{88}$

Notwithstanding this, the applicant had unfortunately overstayed by 12 days after his limit of stay had expired, before he first applied for unconditional stay in Hong Kong. Therefore according to the Director of Immigration, even as of 24 October 1998, the material date when the appellant applied for unconditional stay, he had not met the requirement of being an ordinary resident of Hong Kong for seven continuous years and could not qualify for permanent resident status. $^{89}$ Despite counsel on both sides asking the court to decide there and then whether this brief contravention was material, the court artfully refused their request and remitted the case to the Director of Immigration to redetermine the applicant's eligibility for permanent residency in light of the new material date and standard immigration practices. This decision is very puzzling. As pointed out by counsel for the applicant, if the material date for determining his eligibility for permanent residency was now 24 October 1998, it would be inconceivable that he would be denied his constitutional entitlement to the right of abode just because he had technically overstayed by 12 days, ${ }^{90}$ especially since at that time he was employed and had no prison record. The only reason why the court decided as it did, I believe, was that since that material date, the applicant had been imprisoned three times for assault and had been sentenced to eight months two weeks of imprisonment in all. ${ }^{91}$ This fact was of course irrelevant technically so far as eligibility for the right of abode is concerned, since it occurred after the material date; but being the politically savvy judges they are now, the CFA judges were not going to deny the Director of Immigration an opportunity to remove an undesirable character from Hong Kong if he so chooses, especially since it had really achieved the aim of this appeal, namely to remove

87 Ibid. at 556-7.

88 Ibid. at 578.

89 Ibid. at 580.

90 Ibid. at 582.

91 Ibid. at 564. 
the grant of a constitutional right of abode from the wild clutches of administrative discretion.

Furthermore, two strange cases concerning judicial remedies arose in 2006. In the first, Koo Sze $\mathrm{Yiu}^{92}$ the CFA invalidated a statutory scheme which allowed the Chief Executive, whenever he considered that public interest so required, to order the interception or disclosure of telecommunications to the government. Concerned that an immediate invalidation of the impugned legislation would unduly hamper legitimate covert surveillance activities, the CFA toyed with the idea of either according temporary validity to the impugned scheme or suspending its declaration of invalidity until corrective legislation could be enacted. ${ }^{93}$ The vacillation between the two remedies is curious as the Canadian courts, the ones who first conceived of this remedy, had used both terms interchangeably and had never sought to draw a distinction between the two. ${ }^{94}$ This anomaly was also pointed out by Sir Anthony Mason in his concurring judgment. ${ }^{95}$ According to the majority, the difference between the two remedies lies in the fact that in the former, the executive is shielded from legal liability during the interim period before the corrective legislation comes into force, whilst in the latter, no such immunity is provided ${ }^{96}$ It is very telling that the court cited no authorities for this assertion. The majority went on to suggest that a temporary validity to an otherwise unconstitutional law would only be accorded when a 'virtual legal vacuum' would ensue as a result of its immediate invalidation; in all other instances the only remedy to which the court would resort is the suspension of its declaration of invalidity ${ }^{97}$ Again, no authorities were cited for this legal proposition but it is evident that the court was trying to deter the executive from seeking this remedy on a routine basis whenever a statute was to be deemed unconstitutional.

In the second case, Hung Chan Wah, ${ }^{98}$ the CFA had to decide whether it had the power to engage in a prospective ruling. Ultimately the court did not decide this issue but merely explored possible justifications for and objections to the exercise of this power. ${ }^{99}$

At first blush, it seems unusual for the CFA to be so coy about exercising the right to grant new constitutional remedies. After all, as discussed earlier, the CFA has never shied away from engaging in novel remedial interpretations. ${ }^{100}$ It is my belief that the CFA was so

92 [2006] 3 HKLRD 455.

93 Ibid. at 467.

94 See P. Hogg, Constitutional Law of Canada, Vol. 2, 4th edn (Carswell: Toronto, 1997) para. 37.1(d).

95 [2006] 3 HKLRD 455 at 470-1.

96 Ibid. at 467.

97 Ibid.

98 [2006] 3 HKLRD 841.

99 Ibid. at paras. 28-33. The CFA conceded that this power might be necessary to meet the changing needs of society.

100 See HKSAR v Lam Kwong Wai [2006] 3 HKLRD 808. 
circumspect only because it was fully aware that these new 'powers' were misnomers; in reality, they were respectively limitations on the judicial power to grant immediate invalidity to otherwise unconstitutional laws, and restrictions on the court's power to apply its judgment retrospectively. Having consolidated its powers slowly but surely over the years, it is thus natural for the CFA to be unwilling to relinquish any powers so readily. Astutely, by framing its reluctance to accept a judicial limitation as a disavowal of the right to exercise an 'extraordinary power','101 the court was in effect retaining power under the guise of relinquishing it.

\section{The CFA and a Generous Interpretation of the Basic Law}

In the third category are cases which concern neither the constitutionality of NPCSC Interpretations/PRC laws nor domestic law and order issues. In these instances where the CFA was confident that any political fallout following an adverse decision would be least severe, the CFA had been generous about interpreting the Basic Law and avoiding the austerity of tabulated legalism.

A prime example is the landmark decision of Tse Wai Chun, ${ }^{102}$ where the CFA unanimously held that under the tort of defamation, a comment which falls within the defence of fair comment would only lose its immunity by proof that the defendant did not genuinely hold the view he expressed. ${ }^{103}$ Actuation by spite, animosity, intent to injure or other motivation, even if it is the sole motive, does not of itself defeat the defence. This redefinition of malice for the purpose of negating the defence of fair comment is groundbreaking because, prior to this decision, the conventional wisdom in the Commonwealth suggested that the defendant would be deemed to have been actuated by malice if he had some improper or personal motive when he made the alleged defamatory statement. ${ }^{104}$ Unlike his usual ambivalence toward giving a robust interpretation of constitutional guarantees, Chief Justice Li in his concurrence took pains to emphasize that:

The Courts should adopt a generous approach so that the right of fair comment on matters of public interest is maintained in its full vigour. ${ }^{105}$

In the same vein, the CFA was decisive in invalidating the electoral arrangements in New Territories villages (rural pockets of Hong Kong), ${ }^{106}$ which only allowed indigenous villagers, that is to say persons who could establish patrilineal descent from an ancestor who was in 1898 a resident of an established village in Hong Kong, to vote

101 [2006] 3 HKLRD 841 at para. 33.

102 [2000] 3 HKLRD 418.

103 Ibid. at 438.

104 Ibid. at 433.

$105 \mathrm{Ibid}$. at 422.

106 Secretary for Justice v Chan Wah [2000] 3 HKLRD 641. 
or stand as candidates for village representatives, on the basis that these restrictions denied the non-indigenous villagers the right to take part in the conduct of public affairs as protected under Article 21(a) of the Bill of Rights. ${ }^{107}$ Given that the village representatives had a common duty to represent the villagers as a whole and not just the interests of indigenous villagers, this discrimination against nonindigenous villagers would hardly be justifiable but for Article 40 of the Basic Law. ${ }^{108}$ The indigenous villagers argued that Article 40, which protects the lawful traditional rights and interests of the indigenous inhabitants, implicitly included their political right to vote and stand as candidates in village elections to the exclusion of others. ${ }^{109}$ Whilst the CFA did not reject the possibility that there might be derivative rights which are necessarily implicit within the rights expressly protected under Article 40, the right to exclude the political interests of non-indigenous villagers could not be so implied. ${ }^{110}$ Unfortunately the court did not provide a reason for reaching this conclusion nor did the court offer any clue as to how implied rights under Article 40 could be deduced. What is evidently clear, however, is that the CFA was too eager about promoting political equality to be fettered unnecessarily by legal niceties.

\section{Conclusion}

Chastised by the Mainland government for judicial overreach in $\mathrm{Ng} \mathrm{Ka} \mathrm{Ling,} \mathrm{where} \mathrm{the} \mathrm{Court} \mathrm{of} \mathrm{Final} \mathrm{Appeal} \mathrm{unabashedly} \mathrm{declared}$ the power to review the legislative acts of the National People's Congress, the court meekly retreated into obscurity but only to draw the contempt and chagrin of human rights activists and academic commentators. ${ }^{111}$

The fundamental jurisprudential conundrum which the CFA faces is how it can preserve the judiciary as a separate and independent branch of government whilst quelling any concerns from the Mainland that Hong Kong courts, if left unleashed, would turn the Island into another 'renegade province' in the south.

If the Hong Kong courts are too aggressive in defending the rights of the oppressed minority, they might only incur a backlash that takes the form of an Interpretation from the NPC or even an amendment of the Basic Law. On the other hand, if they are too indulgent towards

107 The Bill of Rights, Art. 21(a) provides: 'Every permanent resident shall have the right and the opportunity ... and without unreasonable restrictions: (a) to take part in the conduct of public affairs, directly or through freely chosen representatives'.

108 The Basic Law, Art. 40 reads: "The lawful traditional rights and interests of the indigenous inhabitants of the "New Territories" shall be protected by the Hong Kong Special Administrative Region'.

109 [2000] 3 HKLRD 641 at 657.

$110 \mathrm{Ibid}$. at 658.

111 Above n. 4. 
the HKSAR government, the Basic Law would be reduced to a mere hollow shell that only protects constitutional rights on paper but not in practice.

After a momentary period of abdication in Lau Kong Yung ${ }^{112}$ and $\mathrm{Ng} \mathrm{Kung} \mathrm{Siu},{ }^{113}$ of late there has been a resurgence of judicial power, a quiet but determined effort by the CFA to put a brake on legislative and executive excesses, but its record is haphazard. It is my belief that the structure I described explains why. In sum, where decisions implicate the validity of NPCSC decisions or PRC laws implemented under the Basic Law, the court would always defer to the central government as the judiciary is fully cognizant, after $\mathrm{Ng} \mathrm{Ka} \mathrm{Ling,} \mathrm{that}$ the central government would not permit bold judicial activism on matters concerning Beijing's sovereignty over the region. Where disputes concern alleged human rights violations that have no PRC implications but have law and order implications in Hong Kong, the court is generally conservative so as to afford the legislature or the executive much latitude in preserving peace and stability, and so as to save its goodwill for controversies where the CFA believes it can triumph. However, in both above-mentioned categories of cases, the judiciary, whilst granting the executive the result it seeks or, at the very minimum, can accept, is very jealous about protecting its own powers of adjudication and takes pains to preserve this prerogative. On the other hand, in rights-infringement controversies with neither NPCSC nor domestic law and order implications, the court is deliberately conscious of avoiding the austerity of tabulated legalism as the justices are probably confident that, in these instances, the backlash from the Mainland or the Hong Kong SAR government would be minimal and thus it would be most opportune for the court to intervene aggressively in such cases and advance the development of human rights in Hong Kong.

For better or worse, this is the CFA's solution to the jurisprudential conundrum of observing civil liberties in this new age of Chinese civil law domination.

Almost 300 years ago, Lord Mansfield once exhorted judges so:

We must not regard political consequences; how formidable soever they might be: if rebellion was the certain consequence, we are bound to say 'fiat justitia ruat coelum' [let justice be done, though the heavens fall]. ${ }^{114}$

Whilst the flagrant judicial disregard of political consequences may have been possible under the common law three centuries back, this approach is no longer prudent in post-colonial Hong Kong where the present legal landscape is the offspring of an unhappy marriage of two strange bedfellows with distinctively different characters. If the 
CFA is blind to the political consequences of its decisions, the executive branch of the SAR government would just circumvent its judgments by routinely using the NPCSC Interpretation to censure the court and fetter its powers further. The CFA, aware that it is possibly the last vanguard of Hong Kong's autonomy and the branch of government most predisposed to safeguarding the region's semiindependence, is thus willing to permit lapses of legal logic and reasoning, to defend the old legal traditions it inherited and resist the new system it was born into.

As the eminent Hong Kong constitutional lawyer, Peter Wesley Smith, once said:

The Basic Law, with all its imperfections, must be made to work, and it cannot be made to work if judges and lawyers close their eyes to 'political fallout' and in the process, deny the constitution's character as a compromise between incompatible systems of law. ${ }^{115}$

The drafting and promulgation of the Basic Law was imbued with so much politics. Can we ever expect its interpretation to be any less political? 
Copyright of Common Law World Review is the property of Vathek Publishing Ltd and its content may not be copied or emailed to multiple sites or posted to a listserv without the copyright holder's express written permission. However, users may print, download, or email articles for individual use. 